\title{
Response of Some Faba Bean Genotypes to Irrigation Water Deficit Grown in Sandy Soil
}

\author{
Mona M. Yousry ${ }^{1 *}$, Sameh A. M. Moussa ${ }^{2}$, and G. Abdel-Nasser ${ }^{3}$
}

\begin{abstract}
Field experiments were conducted at the Faculty of Agriculture, (Saba-Basha) - Alexandria University, Egypt during winter growing seasons of 2017and 2018. Drip irrigation system was used in sandy soil to rate the irrigation water usage and increase its use efficiency, and then maximize Faba beans productivity under water deficit conditions. Four Egyptian Faba bean ecotypes and a commercial cultivar (Cleopatra) were grown under a drip irrigation system for evaluation under water deficit conditions. Four irrigation rate treatments were applied; i.e., $100 \%, 80 \%, 60 \%$, and $40 \%$ of the $\mathrm{ET}_{0}$. The results revealed that the tested Faba bean genotypes differed among themselves in most of the studied traits, whether the vegetative characters, yield, and its component traits and pod characteristics. Most of the studied characters, especially the vegetative characters, leaves chlorophyll content and pods fresh yield/feddan trait were significantly affected by the irrigation rates. The obtained results showed that there was a significant decrease in the values of most of these characters by reducing irrigation rates from $3167\left(100 \%\right.$ of the $\left.\mathrm{ET}_{0}\right)$ down to $1267 \mathrm{~m}^{3} /$ fed. $(40 \%$ of the $\left.\mathrm{ET}_{0}\right)$ in the first season and from $3100(100 \%$ of the $E_{0}$ ) down to $1240 \mathrm{~m}^{3} / \mathrm{fed}$. (40\% of the $\mathrm{ET}_{0}$ ) in the second season. The results showed that the Cleopatra cultivar was the best-tested genotype in terms of irrigation water use efficiency (IWUE). Also, the same cultivar was significantly superior to most of the tested Faba bean ecotypes in terms of growth vigor and productivity, even with irrigation water shortage, down to $2534 \mathrm{~m}^{3}$ / fed. or $2480 \mathrm{~m}^{3}$ / fed. during the first and second seasons $(80 \%$ of the ET ${ }_{0}$ ), respectively. The results of this study showed that, under the conditions of this experiment, it is possible to rationalize irrigation water usage by $20.00 \%$ from the common irrigated treatment to reach the highest irrigation water use efficiency even with a decrease of yield, especially in semi-arid areas with limited water.
\end{abstract}

Keywords: Faba bean, Vicia faba, L., pod fresh yield, pod characteristics, water stress, water deficit, irrigation water use efficiency (IWUE).I

\section{INTRODUCTION}

Faba bean (Vicia faba, L.) is a widely grown crop in Egypt, as beans are a staple food for the majority of the Egyptian people. Faba bean is one of the most important crops of leguminous vegetables. It has a long history of cultivation and used in feed and food (Siddiqui et al., 2015). Faba bean is a cheap source of high-quality protein with high calories and nutritive value for the great majority of the Egyptian people (Radwan and Wafaa, 2005). The seeds contain about $24 \%$ protein, $58 \%$ carbohydrates, and a high proportion of iron and calcium. FAOSTAT (2018) reported that Egypt is one of the main faba bean producing countries where the area harvested in Egypt reached to 40298 ha and the average total production is about 139303 tons.

Countries of the Mediterranean basin, especially the southern Mediterranean region, suffer from insufficient rainfall intensity and irregular distribution during the rainy seasons. This often exposes crops to prolonged periods of drought and subsequent high temperatures (Ricciardi, et al., 2001). Therefore, in semi-arid regions like Egypt, preserving irrigation water and rationing its use by following modern irrigation methods such as drip irrigation is very necessary to maximize the use of irrigation water and not to waste it.

Drought is an environmental stress that directly affect agricultural production, especially in semi-arid regions resulting from global climate change, and water use in agriculture is being reduced. It also severely harms the growth and productivity of crops on the one hand and the other hand does not seriously damage the crop and can lead to higher productivity (Nautiyal et al., 1999). Drought stress is one of the major abiotic stresses that are a threat to crop production worldwide. Drought stress impairs the plants' growth and yield (Siddiqui et al., 2015; Abdul Muktadir et al., 2020).

Water stress is one of the most important environmental stresses causing heavy losses to agriculture worldwide (Kumar et al., 2012; Abid et al.,

DOI: 10.21608/asejaiqjsae.2021.189890

${ }^{1}$ Plant Production Dept., Faculty of Agric., Saba Basha, Alexandria Univ.

${ }^{2}$ Sabaheya Horticulture Research Station, Alexandria, Horticulture Res. Inst., ARC.

${ }^{3}$ Soil and Agricultural Chemistry Dept., Faculty of Agric., Saba Basha, Alexandria Univ.

*Corresponding Author: Plant Production Department -

Vegetable Faculty of Agriculture, Saba Basha, Alexandria University, Egypt.

E-mail: dr.monayousry27776@gmail.com

Received July 15, 2021, Accepted, August 18, 2021. 
2020). Water stress is often accompanied by relatively high temperatures, which increase the effect of drought and significantly reduces crop yields. Selection of drought-tolerant varieties includes choosing to reduce non-transpiration uses of water, reduce transpiration without reducing productivity, increase yields without increasing transpiration, and fluctuation of salinity leads to increase water use efficiency (WUE) (Sorrells et al., 2000; Bennett, 2003; Anjum et al., 2011 and Ghassen et al., 2017).

Faba bean is susceptible to moisture and hightemperature stresses (Loss and Siddique 1997). The water stress that occurs during the vegetative and reproductive stages is one of the main factors limiting the yield of Faba beans, and thus the stability of the cultivated area (Hawtin and Hebblethwaite, 1983 and Ricciardi and Steduto, 1988).

Water stress causes many different adverse effects on leaf stretching and stem elongation, plant photosynthesis activity, due to premature leaf aging, flowering, decrease in self-fertility and seed size and the root and node system (Tamaki and Naka, 1971; Elston et al., 1976 and Dennet, et al., 1979; Karamanos, 1978; Finch-Savage and Elston, 1982; Alvino et al., 1982; Stoddard, 1986; El Nadi, 1970; Tamaki and Naka, 1971; Sprent, 1972; Sprent, 1976; Sprent et al., 1977 and Nanda et al., 1988).

The present experiment evaluate the response of four Egyptian Faba bean local ecotypes and one of commercial cultivar to simulated water stress aiming at the possibility of expanding Faba bean cultivation in limited water areas. In addition, this experiment assigned to maximize irrigation water use efficiency of Faba beans in semi-aired areas.

\section{MATERIALS AND METHODS}

The present investigation was carried out during the two winter seasons of 2017 and 2018. The cultivation was carried out at the Faculty of Agriculture, SabaBash, Alexandria University, Alexandria Governorate, Egypt.

Some physical and chemical analyses of the experimental soil are presented in Table (1). Soil analysis demonstrated that the soil experiment was a sandy texture.

\section{Genetic material source and Experimental layout}

Field experiments were conducted at the Faculty of Agriculture (Saba-Basha), Alexandria University, during winter seasons of 2017and 2018. Planting materials of this study consisted of five Faba bean (Vicia faba, L.) genotypes, i.e., four local ecotypes named Alexandria, El-Behira, Kafr El-Shikh, and ElMenia, and one comercial cultivar, Cleopatra which was planted as a commercial cultivar for comparison. The seeds were planted in rows, $60 \mathrm{~cm}$ apart and at a spacing of $30 \mathrm{~cm}$ within rows at the rate of 1 seed per hill. The area of experimental unit was $12.6 \mathrm{~m}^{2}$ consisted of three-rows ( $7.0 \mathrm{~m}$ long and $0.60 \mathrm{~m}$ width). Planting took place during the winter seasons of 2017 and 2018 on the $5^{\text {th }}$ of November and was harvested on the $30^{\text {th }}$ of March in the two growing seasons. The planting was protected from rainfall by a transparent plastic cover.

\section{Irrigation regimes}

A drip irrigation system was designed for the experiment. Distribution lines consisted of PVC pipe manifolds for each plot. The diameter of the polyethylene laterals was $16 \mathrm{~mm}$ and each lateral irrigated one plant row. The inline emitter discharge rate was $21 \mathrm{~h}^{-1}$.

The experimental layout was presented as a splitplot design with three replicates. Four irrigation treatments $\left(100,80,60\right.$, and $40 \%$ of $\left.\mathrm{ET}_{0}\right)$ were assigned in the main plots, whereas, five faba bean genotypes were random distributed in the sub-plots.

The values of reference evapotranspiration $\left(\mathrm{ET}_{0}\right)$ were calculated using the Penman-Monteith method (Allen et al., 1998) under climatic conditions (Table 2) obtained for the experimental site (NASA, 2020) according to the following equation (Eq. 1):

$$
\mathrm{ET}_{0}=\frac{0.408 \Delta\left(\mathrm{R}_{\mathrm{n}}-\mathrm{G}\right)+\gamma \frac{900}{\mathrm{~T}+273} \mathrm{U}_{2}\left(\mathrm{e}_{\mathrm{s}}-\mathrm{e}_{\mathrm{a}}\right)}{\Delta+\gamma\left(1+0.34 \mathrm{U}_{2}\right)}
$$

Where:

$\mathrm{ET}_{0} \quad$ Reference evapotranspiration, $\mathrm{mm} \mathrm{day}^{-1}$

$\mathrm{R}_{\mathrm{n}} \quad$ Net radiation at the crop surface, $\mathrm{MJ} \mathrm{m}^{-2}$ day $^{-1}$,

G Soil heat flux density, MJ $\mathrm{m}^{-2}$ day $^{-1}$, Generally very small and assumed to be zero).

$\mathrm{T} \quad$ Mean daily air temperature at $2.0 \mathrm{~m}$ height, ${ }^{\circ} \mathrm{C}$,

$\mathrm{U}_{2} \quad$ Wind speed at $2 \mathrm{~m}$ height, $\mathrm{m} \mathrm{s}^{-1}$,

$\mathrm{e}_{\mathrm{s}} \quad$ Saturation vapor pressure at 1.5 to $2.5 \mathrm{~m}$ height, $\mathrm{kPa}$,

$\mathrm{e}_{\mathrm{a}} \quad$ Actual vapor pressure at 1.5 to $2.5 \mathrm{~m}$ height, $\mathrm{kPa}$,

$\mathrm{e}_{\mathrm{s}}-\mathrm{e}_{\mathrm{a}} \quad$ Saturation vapor pressure deficit, $\mathrm{kPa}$,

$\Delta \quad$ Slope vapor pressure curve, $\mathrm{kPa}^{\circ} \mathrm{C}^{-1}$,

$\gamma \quad$ Psychrometric constant, $\mathrm{kPa}^{\circ} \mathrm{C}^{-1}$, 
Table 1. The main physical and chemical properties of the experimental soil.

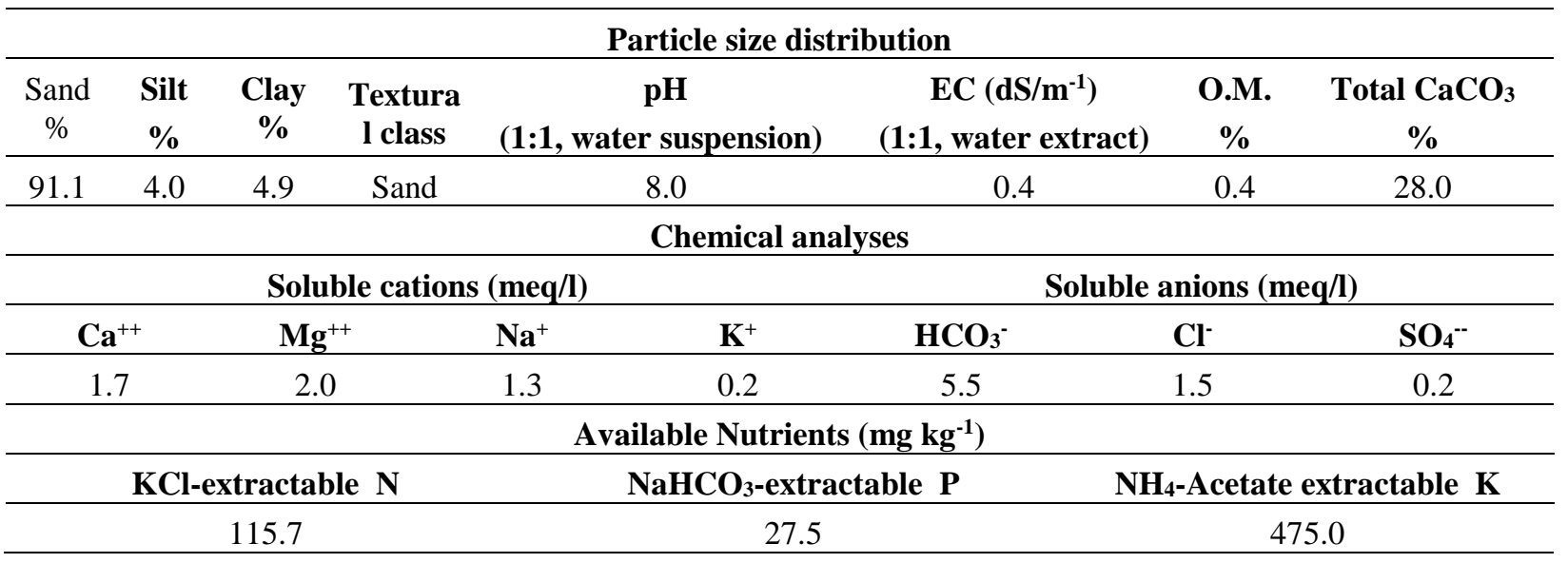

Table 2. The climatic conditions of the experimental site during 2017 and 2018 growing seasons

\begin{tabular}{|c|c|c|c|c|c|c|c|c|c|}
\hline \multirow{3}{*}{ Month } & \multicolumn{9}{|c|}{2017 Growing season } \\
\hline & $\mathbf{P e}$ & U2 & RH & Tdew & $\mathbf{T x}$ & Tn & Tm & $\mathbf{P}$ & RA \\
\hline & $\mathbf{m m}$ & $\mathbf{m} / \mathbf{s}$ & $\%$ & $\mathrm{C}^{\circ}$ & $\mathrm{C}^{\circ}$ & $\mathrm{C}^{\circ}$ & $\mathrm{C}^{\circ}$ & $\mathbf{k P a}$ & $\mathrm{MJ} / \mathrm{m}^{2} / \mathrm{day}$ \\
\hline November & 16.25 & 3.63 & 68.08 & 13.66 & 21.95 & 18.17 & 19.84 & 101.74 & 17.35 \\
\hline December & 12.15 & 4.15 & 71.04 & 12.36 & 19.76 & 16.23 & 17.78 & 101.95 & 14.90 \\
\hline January & 36.61 & 5.17 & 69.84 & 10.16 & 17.61 & 13.89 & 15.60 & 101.87 & 15.90 \\
\hline February & 13.41 & 3.47 & 71.04 & 10.93 & 18.86 & 13.94 & 16.19 & 101.48 & 20.20 \\
\hline \multirow[t]{2}{*}{ March } & 0.05 & 90.14 & 64.85 & 11.23 & 21.54 & 14.93 & 18.00 & 101.34 & 25.55 \\
\hline & \multicolumn{9}{|c|}{2018 Growing season } \\
\hline November & 22.96 & 3.33 & 65.87 & 14.61 & 23.30 & 19.45 & 21.17 & 101.61 & 17.41 \\
\hline December & 63.58 & 4.86 & 68.71 & 11.68 & 19.06 & 16.01 & 17.43 & 101.77 & 14.92 \\
\hline January & 24.92 & 5.37 & 65.39 & 7.79 & 16.64 & 12.07 & 14.21 & 101.54 & 15.90 \\
\hline February & 17.43 & 4.35 & 68.98 & 8.92 & 17.22 & 12.40 & 14.56 & 101.67 & 20.30 \\
\hline March & 7.42 & 4.17 & 70.47 & 10.25 & 18.25 & 13.40 & 15.55 & 101.68 & 25.65 \\
\hline
\end{tabular}

The crop evapotranspiration $\left(\mathrm{ET}_{\mathrm{c}}\right)$ is the daily use of water by Faba beans and calculated using the following equation (Allen et al., 1998), Eq. 2:

$$
\mathrm{ET}_{\mathrm{c}}=\mathrm{K}_{\mathrm{c}} \times \mathrm{ET}_{0}
$$

Where:

$\mathrm{K}_{\mathrm{c}}$ is the crop coefficient

The crop coefficient $(\mathrm{Kc})$ values for different growth stages of the Faba bean (Allen et al., 1998) are shown in Table (3).

Table 3. Crop coefficient of Faba bean according to the growth stages

\begin{tabular}{ll}
\hline Growing stage & Kc value \\
\hline Initial stage & 0.60 \\
Mid-stage & 1.15 \\
End-stage & 0.50 \\
\hline
\end{tabular}

The crop water requirements were calculated according to the Penman-Monteith equation (Allen et $a l ., 1998)$ using the following equation Eq.3; (Cuenca, 1989):

$\mathrm{ET}_{\text {drip }}=\mathrm{K}_{\mathrm{r}} \times \mathrm{K}_{\mathrm{c}} \times \mathrm{ET}_{\mathrm{o}}$

Where:

$\mathrm{ET}_{\text {drip }}$ is the crop water requirements under the drip irrigation system.

$\mathrm{K}_{\mathrm{r}}$ is the reduction factor that reflects the percentage of irrigation treatments.

According to the aforementioned equations, the quantities of irrigation water were calculated. The four irrigation rate treatments $(100,80,60$, and $40 \%$ of the $\mathrm{ET}_{0}$ ) accounted as $3167,2534,1900$, and $1267 \mathrm{~m}^{3} / \mathrm{fed}$ in the first season and 3100, 2480, 1860 and $1240 \mathrm{~m}^{3} / \mathrm{fed}$ in the second season, respectively. 


\section{Agricultural operations:}

Phosphorus fertilizer was applied at the rate of 150 $\mathrm{kg} / \mathrm{fed}$ in the form of super Phosphate $\left(15.5 \% \mathrm{P}_{2} \mathrm{O}_{5}\right)$ during soil preparation, plus 5 tons of compost/fed. Nitrogen fertilizer was applied at the rate of $50 \mathrm{~kg} \mathrm{~N} / \mathrm{fed}$ to the soil in the form of ammonium sulfate $(21.0 \% \mathrm{~N})$ after 30 days of planting. Potassium fertilizer was added at the rate of $50 \mathrm{~kg} / \mathrm{fed}$. in the form of potassium sulfate $\left(48 \% \mathrm{~K}_{2} \mathrm{O}\right)$ throughout the drip irrigation system. All other agricultural practices for Faba bean production were followed as recommended.

\section{MEASUREMENTS AND DATA RECORDED}

\section{Vegetative characters:}

Vegetative characteristics were measured and recorded at 145 days after planting. The plants were randomly taken per each experimental unit, where five plants were taken for measuring plant height $(\mathrm{cm})$, counting the number of branches/plant, the height of the $1^{\text {st }}$ pod $(\mathrm{cm})$, and leaf chlorophyll content $(\mathrm{mg} / 100 \mathrm{~g})$. The total chlorophyll content in leaf tissues was extracted with $100 \% \mathrm{~N}, \mathrm{~N}$-dimethyl formamide and analyzed by UV-Digital spectrophotometer (Spectronic601, Milton Roy), using the methodologies described by Moran (1982).

\section{Yield and yield components:}

Samples of randomly five plants were used, from each experimental unit to record the number of pods per plant, seeds weight per plant (g), and pods fresh weight per plant $(\mathrm{g})$. Net ratio $(\%)$ was calculated by dividing seeds weight per plant on pods fresh weight per plant then multiplied by 100 . Pods fresh weight yield per feddan was determined by calculating pods fresh weight per sub-plot then attributed to feddan.

\section{Pod characteristics:}

The following characteristics of pod were measured and recorded for randomly five plants per an experimental unit: Number of seeds per pod, pod weight $(\mathrm{g})$, and pod length $(\mathrm{cm})$.

\section{Irrigation water - use efficiency (IWUE):}

Irrigation water-use efficiency (IWUE) was calculated as $\mathrm{kg}$ of pods fresh weight yield produced per one cubic meter of applied water (Doorenbos and Kassem, 1979; Ahmed, 1987 and Sharma et al., 2015), using Eq.4.

Produced Pod fresh weight yield $(\mathrm{kg} / \mathrm{fed})$ IWUE $\left(\mathrm{kg} / \mathrm{m}^{3}\right)=$

(4)

$$
\text { Applied irrigation water }\left(\mathrm{m}^{3} / \mathrm{fed}\right)
$$

\section{Statistical analysis}

The collected data were statistically analyzed, using the analysis of variance method. Comparisons among the means of different clones were carried out, using the least significant differences (LSD) test procedure at $p \leq$ 0.05 level of probability, as explained by Snedecor and Cochran (1980) using the Co-Stat software program (2004).

\section{RESULTS AND DISCUSSIONS}

\section{Vegetative characters}

Table (4) showed that the studied vegetative characters were affected by applied irrigation water treatments $(P \leq=0.05)$. In this respect; Irrigation water quantities of 3167 and $2534 \mathrm{~m}^{3} / \mathrm{fed}$ gave the highest mean values for plant height $(\mathrm{cm})$ trait during the two seasons.

The presented data showed that irrigation water quantities of 3167 and $2534 \mathrm{~m}^{3} / \mathrm{fed}$ significantly produced the highest mean values for No. of branches/plant trait during the two seasons. As for the height of the $1^{\text {st }}$ pod; irrigation water quantity of 2534 $\mathrm{m}^{3} /$ fed significantly gave the highest mean values during the two seasons. The data of leaves chlorophyll content showed that the irrigation water quantity of $3167 \mathrm{~m}^{3} /$ fed significantly gave the highest mean values compared with the other tested irrigation water treatments during the two study seasons of the experiment. The decrease in growth parameters might be due to impaired cell division, cell enlargement caused by loss of turgor, and inhibition of various growth metabolism processes (Yordanov et al., 2003 and Farooq et al., 2012). These results reinforce the findings of Ali et al. (2013) and Ouzounidou et al. (2014) on beans; Farooq et al. (2008) on rice and Asrar and Elhindi (2011) on marigolds, who reported that drought stress reduced plant growth properties.

As for Faba bean genotypes, the results in Table (4) showed that Faba bean genotypes significantly differed from each other according to the studied vegetative characteristics. It was found that the two genotypes, Alexandria and Cleopatra, significantly outperformed the rest of the tested cultivars regarding the plant height characteristic during the two seasons of this study. The results showed that El-Behira genotype outperformed the rest of the tested genotypes in terms of the number of branches per plant trait during the two study seasons. As for the characteristic of the height of the $1^{\text {st }}$ pod, the results were very close, as the results obtained did not give any significant differences between the genotypes of Alexandria, El-Beheira, El-Minya, and Cleopatra. 
Table 4. Mean values of vegetative characters of Faba bean genotypes recorded during the seasons of 2017 and 2018.

\begin{tabular}{|c|c|c|c|c|c|c|c|c|c|}
\hline \multirow{2}{*}{\multicolumn{2}{|c|}{ Treatments }} & \multicolumn{2}{|c|}{ Plant height (cm) } & \multicolumn{2}{|c|}{ No. of branches / plant } & \multicolumn{2}{|c|}{ Height of the $1^{\text {st }}$ pod $(\mathrm{cm})$} & \multicolumn{2}{|c|}{ Leaves chlorophyll content $(\mathrm{mg} / 100 \mathrm{~g})$} \\
\hline & & \multirow{2}{*}{2017} & \multirow{2}{*}{2018} & 2017 & \multirow{2}{*}{$\begin{array}{c}2018 \\
e n t, \% \text { of }\end{array}$} & \multirow[t]{2}{*}{2017} & \multirow[t]{2}{*}{2018} & \multirow[t]{2}{*}{2017} & \multirow[t]{2}{*}{2018} \\
\hline \multicolumn{3}{|c|}{ Irrigation treatment, $\%$ of $\mathrm{ET}_{0}$} & & & & & & & \\
\hline 100 & & $127.00 \mathrm{a}$ & $112.60 \mathrm{ab}$ & $9.93 \mathrm{a}$ & $9.13 \mathrm{a}$ & $22.40 \mathrm{~b}$ & $20.53 \mathrm{~b}$ & $85.54 \mathrm{a}$ & $82.70 \mathrm{a}$ \\
\hline 80 & & $120.53 \mathrm{ab}$ & $117.40 \mathrm{a}$ & $9.87 \mathrm{a}$ & $9.20 \mathrm{a}$ & $26.13 \mathrm{a}$ & $23.40 \mathrm{a}$ & $83.65 \mathrm{~b}$ & $81.41 \mathrm{~b}$ \\
\hline 60 & & $113.60 \mathrm{~b}$ & $110.07 \mathrm{~b}$ & $8.60 \mathrm{~b}$ & $7.73 \mathrm{~b}$ & $17.47 \mathrm{c}$ & $15.33 \mathrm{c}$ & $77.75 \mathrm{c}$ & $75.43 \mathrm{c}$ \\
\hline 40 & & $79.53 \mathrm{c}$ & $77.67 \mathrm{c}$ & $6.47 \mathrm{c}$ & $5.93 \mathrm{c}$ & $15.40 \mathrm{~d}$ & $14.13 \mathrm{c}$ & $66.18 \mathrm{~d}$ & $63.66 \mathrm{~d}$ \\
\hline \multicolumn{10}{|c|}{ Genotypes } \\
\hline Alex & adria & $117.83 \mathrm{a}$ & $108.42 \mathrm{ab}$ & $10.17 \mathrm{~b}$ & $9.17 \mathrm{~b}$ & $22.33 \mathrm{a}$ & $19.33 \mathrm{a}$ & $77.88 \mathrm{~b}$ & $75.36 \mathrm{c}$ \\
\hline El-B & nira & $110.58 \mathrm{~b}$ & $103.92 \mathrm{bc}$ & $11.33 \mathrm{a}$ & $10.42 \mathrm{a}$ & $20.17 \mathrm{ab}$ & $18.17 \mathrm{ab}$ & $78.36 \mathrm{~b}$ & $75.44 \mathrm{c}$ \\
\hline Kafr & 1-Shikh & $108.00 \mathrm{~b}$ & $103.08 \mathrm{c}$ & $6.58 \mathrm{~d}$ & $6.25 \mathrm{~d}$ & $18.00 \mathrm{~b}$ & $17.25 \mathrm{~b}$ & $78.17 \mathrm{~b}$ & $76.28 \mathrm{~b}$ \\
\hline El-M & & $98.17 \mathrm{c}$ & $95.25 \mathrm{~d}$ & $7.75 \mathrm{c}$ & $7.17 \mathrm{c}$ & $20.17 \mathrm{ab}$ & $18.58 \mathrm{ab}$ & $75.36 \mathrm{c}$ & $72.40 \mathrm{~d}$ \\
\hline Cleo & atra & $116.25 \mathrm{a}$ & $111.50 \mathrm{a}$ & $7.75 \mathrm{c}$ & $7.00 \mathrm{c}$ & $21.08 \mathrm{a}$ & $18.42 \mathrm{ab}$ & $81.63 \mathrm{a}$ & $79.52 \mathrm{a}$ \\
\hline \multicolumn{10}{|c|}{ Irrigation treatment, \% of ET 0 X Genotypes } \\
\hline \multirow{5}{*}{8} & Alexandria & $133.00 \mathrm{abc}$ & $105.33 \mathrm{de}$ & $12.33 \mathrm{~b}$ & $12.00 \mathrm{a}$ & $25.33 \mathrm{bcd}$ & $22.67 \mathrm{bcd}$ & 84.39 cde & $82.17 \mathrm{~cd}$ \\
\hline & El-Behira & $124.00 \mathrm{~cd}$ & $105.33 \mathrm{de}$ & $14.00 \mathrm{a}$ & $12.33 \mathrm{a}$ & 17.67 ghij & $16.33 \mathrm{gh}$ & $85.29 \mathrm{c}$ & $81.33 \mathrm{de}$ \\
\hline & Kafr El-Shikh & $124.33 \mathrm{~cd}$ & $113.00 \mathrm{~cd}$ & $6.00 \mathrm{fg}$ & $5.33 \mathrm{ij}$ & 24.00 bcde & $22.33 \mathrm{~cd}$ & $84.94 \mathrm{~cd}$ & $83.16 \mathrm{c}$ \\
\hline & El-Menia & $115.00 \mathrm{de}$ & $112.00 \mathrm{~d}$ & $8.67 \mathrm{~d}$ & 8.00 ef & 24.67 bcde & $23.00 \mathrm{bcd}$ & $81.64 \mathrm{~g}$ & $77.59 \mathrm{f}$ \\
\hline & Cleopatra & $138.67 \mathrm{a}$ & $127.33 \mathrm{ab}$ & $8.67 \mathrm{~d}$ & $8.00 \mathrm{ef}$ & $20.33 \mathrm{efg}$ & $18.33 \mathrm{fg}$ & $91.45 \mathrm{a}$ & $89.26 \mathrm{a}$ \\
\hline \multirow{5}{*}{$\infty$} & Alexandria & $124.33 \mathrm{~cd}$ & $121.33 \mathrm{bc}$ & $10.67 \mathrm{c}$ & $9.67 \mathrm{~cd}$ & $27.67 \mathrm{abc}$ & $25.00 \mathrm{abc}$ & $82.99 \mathrm{f}$ & $80.38 \mathrm{e}$ \\
\hline & El-Behira & $125.33 \mathrm{bcd}$ & $121.67 \mathrm{bc}$ & $12.00 \mathrm{bc}$ & $11.33 \mathrm{ab}$ & $28.67 \mathrm{ab}$ & $26.33 \mathrm{a}$ & $84.25 \mathrm{de}$ & $82.05 \mathrm{~d}$ \\
\hline & Kafr El-Shikh & $125.33 \mathrm{bcd}$ & $122.00 \mathrm{bc}$ & $6.67 \mathrm{ef}$ & 6.33 ghi & 20.00 efgh & $18.33 \mathrm{fg}$ & 83.70 ef & $81.98 \mathrm{~d}$ \\
\hline & El-Menia & $92.67 \mathrm{f}$ & 89.33 f & $9.00 \mathrm{~d}$ & $8.33 \mathrm{def}$ & $23.33 \mathrm{cdef}$ & $22.00 \mathrm{de}$ & $79.68 \mathrm{~h}$ & $77.24 \mathrm{f}$ \\
\hline & Cleopatra & $135.00 \mathrm{ab}$ & $132.67 \mathrm{a}$ & $11.00 \mathrm{bc}$ & $10.33 \mathrm{bc}$ & $31.00 \mathrm{a}$ & $25.33 \mathrm{ab}$ & $87.62 \mathrm{~b}$ & $85.40 \mathrm{~b}$ \\
\hline
\end{tabular}


Cont. Table 4. Mean values of vegetative characters of Faba bean genotypes recorded during the seasons of 2017 and 2018.

\begin{tabular}{|c|c|c|c|c|c|c|c|c|c|}
\hline \multirow{2}{*}{\multicolumn{2}{|c|}{ Treatments }} & \multicolumn{2}{|c|}{ Plant height (cm) } & \multicolumn{2}{|c|}{ No. of branches / plant } & \multicolumn{2}{|c|}{ Height of the $1^{\text {st }}$ pod $(\mathrm{cm})$} & \multicolumn{2}{|c|}{ Leaves chlorophyll content $(\mathrm{mg} / 100 \mathrm{~g})$} \\
\hline & & 2017 & 2018 & 2017 & 2018 & 2017 & 2018 & 2017 & 2018 \\
\hline \multirow{5}{*}{8} & Alexandria & $133.67 \mathrm{abc}$ & $128.67 \mathrm{ab}$ & $9.00 \mathrm{~d}$ & $7.33 \mathrm{fgh}$ & 15.33 hijk & $10.33 \mathrm{j}$ & $77.57 \mathrm{i}$ & $74.92 \mathrm{~h}$ \\
\hline & El-Behira & $112.00 \mathrm{e}$ & $111.33 \mathrm{~d}$ & $10.67 \mathrm{c}$ & $10.00 \mathrm{bc}$ & 17.76 ghij & $16.33 \mathrm{gh}$ & $77.33 \mathrm{i}$ & $74.49 \mathrm{~h}$ \\
\hline & Kafr El-Shikh & $111.67 \mathrm{e}$ & $107.67 \mathrm{de}$ & $9.00 \mathrm{~d}$ & 9.00 cde & 17.33 ghij & $16.67 \mathrm{fg}$ & $77.47 \mathrm{i}$ & $76.07 \mathrm{~g}$ \\
\hline & El-Menia & $105.67 \mathrm{e}$ & $101.67 \mathrm{e}$ & $6.67 \mathrm{ef}$ & $6.00 \mathrm{hi}$ & 18.00 ghij & $16.33 \mathrm{gh}$ & $76.80 \mathrm{i}$ & $74.26 \mathrm{~h}$ \\
\hline & Cleopatra & $105.00 \mathrm{e}$ & $101.00 \mathrm{e}$ & $7.67 \mathrm{de}$ & 6.33 ghi & 19.00 fghi & $17.00 \mathrm{fg}$ & $79.60 \mathrm{~h}$ & $77.43 \mathrm{f}$ \\
\hline \multirow{5}{*}{ f } & Alexandria & $80.33 \mathrm{gh}$ & $78.33 \mathrm{gh}$ & $8.67 \mathrm{~d}$ & $7.76 \mathrm{efg}$ & $21.00 \mathrm{defg}$ & 19.33 ef & $66.59 \mathrm{k}$ & $63.97 \mathrm{j}$ \\
\hline & El-Behira & $81.00 \mathrm{gh}$ & $77.33 \mathrm{gh}$ & $8.67 \mathrm{~d}$ & 8.00 ef & 16.67 ghij & $13.67 \mathrm{hi}$ & $66.57 \mathrm{k}$ & $63.91 \mathrm{j}$ \\
\hline & Kafr El-Shikh & $70.67 \mathrm{~h}$ & $69.67 \mathrm{~h}$ & $6.00 \mathrm{fg}$ & $4.33 \mathrm{jk}$ & $10.67 \mathrm{k}$ & $11.67 \mathrm{ij}$ & $66.57 \mathrm{k}$ & $63.93 \mathrm{j}$ \\
\hline & El-Menia & $79.33 \mathrm{gh}$ & $78.00 \mathrm{gh}$ & 6.67 ef & 6.33 ghi & $14.67 \mathrm{ijk}$ & $13.00 \mathrm{ij}$ & 63.321 & $60.52 \mathrm{k}$ \\
\hline & Cleopatra & $86.33 \mathrm{fg}$ & $85.00 \mathrm{fg}$ & $3.67 \mathrm{~h}$ & $3.33 \mathrm{k}$ & $14.00 \mathrm{jk}$ & $13.00 \mathrm{ij}$ & $67.83 \mathrm{j}$ & $66.00 \mathrm{i}$ \\
\hline
\end{tabular}

Means followed by a similar letter within a column for each parameter are not significantly different at the 0.05 level of probability by L.S.D. test procedure. 
Table (4) showed that Cleopatra cv. significantly gave the highest mean values for leaves chlorophyll content during the two study seasons; whereas, ElMenia ecotype gave the lowest mean values, in this respect, during the two seasons.

In terms of the interaction between the two studied independent variables (irrigation water treatments and Faba bean genotypes) on the vegetative traits, Table (4) showed that the studied vegetative traits significantly affected $(p \leq 0.05)$ with these two independent variables during the two growing seasons. As for the first season, Cleopatra cultivar at $100 \%$ of $\mathrm{ET}_{0}$ gave the highest mean value for plant height $(\mathrm{cm})$ and at $80 \%$ of $\mathrm{ET}_{0}$ in the second season. No. of branches reached a maximum value at $100 \%$ of the $\mathrm{ET}_{0}$ in both seasons. Also, $80 \%$ of the $\mathrm{ET}_{0}$ have highest values of the highest $1^{\text {st }}$ pod for ElBehira and Celeopatra cultivars in both seasons. The leaf chlorophyll content was reached the highest value at 100 and $80 \%$ of the $\mathrm{ET}_{0}$ in both seasons.

\section{Yield and yield component characteristics}

Table (5) showed that irrigation water treatments significantly affected most of the studied yield and yield component characters except for many pods per plant during the two growing seasons. In this respect; irrigation of Faba bean growing at $100 \%$ of $\mathrm{ET}_{0}$ gave the highest mean values over a two-year trial regarding seeds weight/plant $(\mathrm{g})$, pods fresh weight/plant $(\mathrm{g})$, net ratio (\%), and pods fresh weight yield/feddan (ton). The decrease in the yield (ton/fed.) a result of water shortage might be due to the remarkable weakness of the vegetative growth represented in the characteristics of plant height and the number of branches (Table 4), in addition to decrease in the percentage of chlorophyll in plant leaves (Table, 4).

Yield reduction could be due to the role of water stress in plant physiology, especially at flowering and grain filling stages which later reduced plant height through reduced translocation of assimilates to the reproduction sink. On the other hand, Mohan et al. (1982) attributed the reduction in seed yield, under water stress, to the depressive effect of soil moisture on plant stand and on the number of pods per plant. The crop was affected to the same degree of permanent stress from pre-flowering to harvest, indicating that flowering is highly sensitive to water stress. Water stress during pods filling difficulty affected nitrogen as activity and biomass production of the tested cultivars (Plies-Balzer et al., 1995; Ghassen et al., 2017).

In terms of the tested Faba bean genotypes; regarding yield and its component characters, Table (5) showed that most of the studied characters were significantly affected due to Faba bean genotypes, except for net ratio (\%) during the second experimental season. Cleopatra cultivar gave the highest mean values for the trait of the number of pods/plant without any significant differences with each of Kafr El-Shikh and El-Menia ecotypes. Also, in the second season of the experiment, Cleopatra cultivar gave the highest values for No. of pods/plant without significant differences with Kafr El-Shikh ecotype.

As for seeds weight per plant (g) trait; the data of Table (5) showed that Cleopatra cultivar significantly possessed the highest mean values during the two seasons of this study. The same trend of results was obtained concerning pod fresh weight per plant $(\mathrm{g})$ and pod fresh weight yield per feddan (ton), as Cleopatra cultivar significantly achieved the best mean values compared to the rest of the tested genotypes during the two study seasons.

As for the net ratio (\%) characteristic, the significant differences were slight between the studied Faba bean genotypes during the first season of the experiment, while there were no significant differences between those genotypes during the second season. The obvious differences among the tested Faba bean genotypes concerning the most studied characters indicated that there are genetic variances among the tested genotypes.

The interaction between the two studied independent variables (irrigation water quantities and Faba bean genotypes) on the yield and its component characters, Table (5) showed that the studied traits significantly affected $(p \leq 0.05)$ with these two independent variables during the two study seasons. Generally, Cleopatra cultivar $\times 100 \%$ of $\mathrm{ET}_{0}$ significantly gave the highest mean values for most of the studied traits; i.e., [seeds weight/plant $(\mathrm{g})$, pods fresh weight/plant $(\mathrm{g})$ and net ratio (\%)] during the two study seasons. As for No. of pods/plant, The results were not sufficiently clear during the two seasons of the study, as there were no significant differences between most of the applied treatments, and there was no clear direction for the conclusive results obtained, indicating that this trait needs further study to clarify its impact on the treatments under study. However, these results can be explained by the fact that the plant, in a state of water shortage (under conditions of water stress), is trying to give rapid production even before the completion of the vegetative growth phase, lest the end of its life cycle without production, and therefore the plant may accelerate the production of a large number of pods before The end of its life cycle, which explains the increase in the number of pods per plant even under conditions of severe water shortage. 
Table 5. Mean values of yield and its components characteristics of faba bean genotypes recorded during the seasons of 2017 and 2018.

\begin{tabular}{|c|c|c|c|c|c|c|c|c|c|c|c|}
\hline & \multirow{2}{*}{ Treatments } & \multicolumn{2}{|c|}{ No. of pods/plant } & \multicolumn{2}{|c|}{$\begin{array}{c}\text { Seeds weight/plant } \\
\text { (g) }\end{array}$} & \multicolumn{2}{|c|}{$\begin{array}{c}\text { pods fresh weight/plant } \\
\text { (g) }\end{array}$} & \multicolumn{2}{|c|}{$\begin{array}{c}\text { Net ratio } \\
(\%)\end{array}$} & \multicolumn{2}{|c|}{$\begin{array}{l}\text { Pods fresh weight } \\
\text { yield / feddan (ton) }\end{array}$} \\
\hline & & 2017 & 2018 & 2017 & 2018 & 2017 & 2018 & 2017 & 2018 & 2017 & 2018 \\
\hline \multicolumn{12}{|c|}{ Irrigation treatment, \% of ET0 } \\
\hline 100 & & $21.33 \mathrm{a}$ & $19.27 \mathrm{a}$ & $220.91 \mathrm{a}$ & $196.59 \mathrm{a}$ & $448.87 \mathrm{a}$ & $408.47 \mathrm{a}$ & $49.21 \mathrm{a}$ & $48.11 \mathrm{a}$ & $10.00 \mathrm{a}$ & $9.14 \mathrm{a}$ \\
\hline 80 & & $21.33 \mathrm{a}$ & $19.47 \mathrm{a}$ & $187.81 \mathrm{~b}$ & $164.13 b$ & $385.60 \mathrm{~b}$ & $345.73 b$ & $48.68 \mathrm{~b}$ & $47.43 \mathrm{a}$ & $8.63 \mathrm{~b}$ & $7.75 \mathrm{~b}$ \\
\hline 60 & & $21.00 \mathrm{a}$ & $19.27 \mathrm{a}$ & $151.67 \mathrm{c}$ & $127.58 \mathrm{c}$ & $326.80 \mathrm{c}$ & $290.00 \mathrm{c}$ & $46.42 \mathrm{c}$ & $43.40 \mathrm{~b}$ & $7.07 \mathrm{c}$ & $6.17 \mathrm{c}$ \\
\hline 40 & & $20.93 \mathrm{a}$ & $19.27 \mathrm{a}$ & $117.54 \mathrm{~d}$ & $97.73 \mathrm{~d}$ & $266.27 \mathrm{~d}$ & $225.33 \mathrm{~d}$ & $44.17 \mathrm{~d}$ & $43.43 \mathrm{~b}$ & $5.57 \mathrm{~d}$ & $4.66 \mathrm{~d}$ \\
\hline \multicolumn{12}{|c|}{ Genotypes } \\
\hline \multicolumn{2}{|c|}{ Alexandria } & $19.92 \mathrm{~b}$ & $18.17 \mathrm{c}$ & $160.65 \mathrm{c}$ & $136.28 \mathrm{~d}$ & $338.25 \mathrm{~d}$ & $297.67 \mathrm{~d}$ & $47.23 \mathrm{ab}$ & $45.47 \mathrm{a}$ & $7.35 \mathrm{~d}$ & $6.54 \mathrm{c}$ \\
\hline \multicolumn{2}{|c|}{ El-Behira } & $20.58 b$ & $19.00 \mathrm{bc}$ & $163.89 \mathrm{c}$ & $140.40 \mathrm{c}$ & $345.25 \mathrm{c}$ & $307.00 \mathrm{c}$ & $47.08 \mathrm{ab}$ & $45.47 \mathrm{a}$ & $7.60 \mathrm{c}$ & $6.84 \mathrm{c}$ \\
\hline \multicolumn{2}{|c|}{ Kafr El-Shikh } & $21.92 \mathrm{a}$ & $19.83 \mathrm{ab}$ & $172.07 \mathrm{~b}$ & $149.68 \mathrm{~b}$ & $361.25 \mathrm{~b}$ & $321.00 \mathrm{~b}$ & $47.30 \mathrm{a}$ & $45.43 \mathrm{a}$ & $7.89 \mathrm{~b}$ & $6.97 \mathrm{~b}$ \\
\hline \multicolumn{2}{|c|}{ El-Menia } & $21.33 \mathrm{a}$ & $19.33 b$ & $171.89 \mathrm{~b}$ & $147.39 \mathrm{~b}$ & $360.25 \mathrm{~b}$ & $321.67 \mathrm{~b}$ & $47.24 \mathrm{a}$ & $45.48 \mathrm{a}$ & $7.92 \mathrm{~b}$ & $7.04 \mathrm{~b}$ \\
\hline \multicolumn{2}{|c|}{ Cleopatra } & $22.00 \mathrm{a}$ & $20.25 \mathrm{a}$ & $179.51 \mathrm{a}$ & $158.78 \mathrm{a}$ & $379.42 \mathrm{a}$ & $339.58 \mathrm{a}$ & $46.75 \mathrm{~b}$ & $46.13 \mathrm{a}$ & $8.32 \mathrm{a}$ & $7.43 \mathrm{a}$ \\
\hline \multicolumn{12}{|c|}{ Irrigation treatment, \% of ET0 X Genotypes } \\
\hline \multirow{5}{*}{8} & Alexandria & $20.33 \mathrm{def}$ & $18.33 \mathrm{~cd}$ & $216.13 \mathrm{bc}$ & $191.00 \mathrm{c}$ & $441.33 \mathrm{bc}$ & $398.00 \mathrm{~b}$ & $48.97 \mathrm{ab}$ & $48.00 \mathrm{abc}$ & $9.74 \mathrm{c}$ & $9.12 \mathrm{ab}$ \\
\hline & El-Behira & $21.33 \mathrm{bcd}$ & $19.00 \mathrm{bcd}$ & $216.67 \mathrm{bc}$ & $189.67 \mathrm{c}$ & $442.67 \mathrm{bc}$ & $403.33 \mathrm{~b}$ & $48.95 \mathrm{ab}$ & $47.03 \mathrm{abcd}$ & $9.90 \mathrm{bc}$ & $8.97 \mathrm{~b}$ \\
\hline & Kafr El-Shikh & $21.00 \mathrm{cde}$ & $18.67 \mathrm{bcd}$ & $223.10 \mathrm{~b}$ & $201.33 b$ & $454.00 \mathrm{~b}$ & $412.00 \mathrm{ab}$ & $49.14 \mathrm{ab}$ & $48.87 \mathrm{ab}$ & $10.14 b$ & $9.17 \mathrm{ab}$ \\
\hline & El-Menia & 21.00 cde & $19.33 \mathrm{abcd}$ & $215.57 \mathrm{c}$ & $190.30 \mathrm{c}$ & $437.67 \mathrm{c}$ & $403.33 \mathrm{~b}$ & $49.26 \mathrm{ab}$ & $47.07 \mathrm{abcd}$ & $9.75 \mathrm{c}$ & $9.00 \mathrm{~b}$ \\
\hline & Cleopatra & $23.00 \mathrm{a}$ & $21.00 \mathrm{a}$ & $233.07 \mathrm{a}$ & $210.63 \mathrm{a}$ & $468.67 \mathrm{a}$ & $424.67 \mathrm{a}$ & $49.73 \mathrm{a}$ & $49.60 \mathrm{a}$ & $10.47 \mathrm{a}$ & $9.46 \mathrm{a}$ \\
\hline \multirow{5}{*}{$\infty$} & Alexandria & $20.00 \mathrm{def}$ & $18.33 \mathrm{~cd}$ & $165.33 \mathrm{f}$ & $142.27 \mathrm{f}$ & $345.67 \mathrm{f}$ & $305.00 \mathrm{~d}$ & $47.82 \mathrm{~cd}$ & 46.64 bcde & $7.74 \mathrm{f}$ & $6.82 \mathrm{~d}$ \\
\hline & El-Behira & $21.00 \mathrm{cde}$ & $19.00 \mathrm{bcd}$ & $179.67 \mathrm{e}$ & $152.67 \mathrm{e}$ & $369.00 \mathrm{e}$ & $330.67 \mathrm{c}$ & $48.70 \mathrm{bc}$ & 46.17 bcdef & $8.28 \mathrm{e}$ & $7.40 \mathrm{c}$ \\
\hline & Kafr El-Shikh & $22.00 \mathrm{abc}$ & $20.33 \mathrm{ab}$ & $187.90 \mathrm{~d}$ & $166.23 \mathrm{~d}$ & $383.33 \mathrm{~d}$ & $345.00 \mathrm{c}$ & $49.02 \mathrm{ab}$ & $48.18 \mathrm{abc}$ & $8.62 \mathrm{~d}$ & $7.73 \mathrm{c}$ \\
\hline & El-Menia & $21.00 \mathrm{cde}$ & $18.67 \mathrm{bcd}$ & $190.13 \mathrm{~d}$ & $165.83 \mathrm{~d}$ & $387.33 \mathrm{~d}$ & $342.33 \mathrm{c}$ & $49.09 \mathrm{ab}$ & $48.44 \mathrm{ab}$ & $8.70 \mathrm{~d}$ & $7.67 \mathrm{c}$ \\
\hline & Cleopatra & $22.67 \mathrm{ab}$ & $21.00 \mathrm{a}$ & $216.00 \mathrm{c}$ & $193.67 \mathrm{c}$ & $442.67 \mathrm{bc}$ & $405.67 \mathrm{~b}$ & $48.80 \mathrm{ab}$ & $47.74 \mathrm{abc}$ & $9.83 \mathrm{bc}$ & $9.12 \mathrm{ab}$ \\
\hline
\end{tabular}


Cont. Table 5. Mean values of yield and its components characteristics of faba bean genotypes recorded during the seasons of 2017 and 2018.

\begin{tabular}{|c|c|c|c|c|c|c|c|c|c|c|c|}
\hline & \multirow{2}{*}{ Treatments } & \multicolumn{2}{|c|}{ No. of pods/plant } & \multicolumn{2}{|c|}{ Seeds weight/plant (g) } & \multicolumn{2}{|c|}{$\begin{array}{c}\text { pods fresh } \\
\text { weight/plant }\end{array}$} & \multicolumn{2}{|c|}{ Net ratio $(\%)$} & \multicolumn{2}{|c|}{$\begin{array}{l}\text { Pods fresh weight } \\
\text { yield / feddan (ton) }\end{array}$} \\
\hline & & 2017 & 2018 & 2017 & 2018 & 2017 & 2018 & 2017 & 2018 & 2017 & 2018 \\
\hline \multirow[b]{2}{*}{8} & El-Behira & 20.33 def & $19.33 \mathrm{abcd}$ & $152.23 \mathrm{~g}$ & $129.30 \mathrm{gh}$ & $326.00 \mathrm{~g}$ & $288.67 \mathrm{e}$ & $46.71 \mathrm{ef}$ & 44.82 defg & $7.08 \mathrm{gh}$ & $6.14 \mathrm{e}$ \\
\hline & Kafr El-Shikh & $22.67 \mathrm{ab}$ & $20.33 \mathrm{ab}$ & $152.80 \mathrm{~g}$ & $127.67 \mathrm{gh}$ & $326.00 \mathrm{~g}$ & $291.67 \mathrm{de}$ & $46.86 \mathrm{de}$ & $40.70 \mathrm{i}$ & $7.29 \mathrm{gh}$ & $6.22 \mathrm{e}$ \\
\hline \multirow{4}{*}{ f } & Alexandria & $20.00 \mathrm{def}$ & $18.33 \mathrm{~cd}$ & $110.00 \mathrm{j}$ & $89.17 \mathrm{j}$ & $242.00 \mathrm{i}$ & $200.67 \mathrm{~g}$ & $45.46 \mathrm{gh}$ & 44.44 defgh & $5.05 \mathrm{j}$ & $4.12 \mathrm{~h}$ \\
\hline & El-Behira & 19.67 ef & $18.67 \mathrm{bcd}$ & $107.00 \mathrm{j}$ & $89.98 \mathrm{j}$ & $243.33 \mathrm{i}$ & $205.33 \mathrm{~g}$ & $43.97 \mathrm{i}$ & 43.84 efgh & $5.15 \mathrm{j}$ & $4.22 \mathrm{~h}$ \\
\hline & Kafr El-Shikh & $22.00 \mathrm{abc}$ & $20.00 \mathrm{abc}$ & $124.47 \mathrm{hi}$ & $103.50 \mathrm{i}$ & $281.67 \mathrm{~h}$ & $235.33 \mathrm{f}$ & $44.19 \mathrm{i}$ & $43.99 \mathrm{efgh}$ & $5.72 \mathrm{i}$ & $4.75 \mathrm{~g}$ \\
\hline & El-Menia & $22.00 \mathrm{abc}$ & $19.67 \mathrm{abc}$ & $126.87 \mathrm{~h}$ & $105.50 \mathrm{i}$ & $284.33 \mathrm{~h}$ & $245.00 \mathrm{f}$ & $44.60 \mathrm{hi}$ & 43.07 ghi & $6.03 \mathrm{i}$ & $5.20 \mathrm{f}$ \\
\hline
\end{tabular}

Means followed by a similar letter within a column for each parameter are not significantly different at the 0.05 level of probability by L.S.D. test procedure. 
As for pod's fresh weight yield per feddan (ton), the obtained data showed that Cleopatra cultivar $\times 100 \%$ of $\mathrm{ET}_{0}$ significantly gave the highest mean value in this respect during the first season (Table, 5). The data of the second season showed that Cleopatra cultivar $\times 100 \%$ of $\mathrm{ET}_{0}$ gave the highest mean value for pods fresh weight yield per feddan (ton) character without significant differences with each of the treatments Alexandria genotype $\times 100 \%$ of $\mathrm{ET}_{0}$, Kafr El-Shikh genotype $\times$ $100 \%$ of $\mathrm{ET}_{0}$ and Cleopatra cultivar $\times 2764.28 \mathrm{~m}^{3}$ irrigation water/fed.

The optimistic effects of the control irrigation treatment $\left(100 \%\right.$ of $\left.\mathrm{ET}_{0}\right)$ on the pods' fresh weight yield/Fed. and its constituent properties (No. of pods/plant, seeds weight/plant, pods fresh weight/plant, and net ratio) could be linked to moderate soil moisture content, resulting in increased nutrient availability and uptake; also, Soil salinity is low compared to the low field capacity (40\% of $\mathrm{ET}_{0}$ ). Ghosh et al. (2000) illustrated that the higher values of field capacity increased growth indices, which was reflected in higher rates of photosynthesis and carbohydrate production resulting in higher final production. However, the decrease in total productivity due to water stress may be attributed to the decrease in leaf area due to fewer and smaller leaves, increased stomatal resistance (Abid et al., 2020), and gas exchange; In addition to a decrease in the transpiration rate, which led to a decrease in photosynthesis. The developmental stage of the plant and the magnitude of the water deficit determine the loss of Faba bean yield. The most susceptible stages of growth inhibition have been differently described as flowering (El-Nadi, 1969), early podding (Mwanamwenge et al., 1999), and pod setting (Xia, 1994), but all of these studies generally agree that the early reproductive stage is the most sensitive (Khan et al., 2007; Alghamdi et al., 2015). Moderate drought stress had a negative effect on the number of pods per plant trait but did not affect the size of the seeds or the number of seeds per pod traits (El-Nadi, 1969 and Adisarwanto and Knight, 1997). The extent of water deficit determined whether the plant partially suffered damage or completely death.

\section{Pod characteristics}

Table (6) showed that water treatments treatments significantly affected the studied pod characteristics $(P$ $\leq=0.05$ ) during the two study seasons. In this regard; irrigation of Faba bean plants at a rate of $3167 \mathrm{~m}^{3} / \mathrm{fed}$. $\left(100 \%\right.$ of $\left.\mathrm{ET}_{0}\right)$ possessed the highest mean values over a two-year trial regarding pod weight (g) trait. As for No. of seeds/pod; the recorded data showed that irrigation water quantity of $3167 \mathrm{~m}^{3} / \mathrm{fed}$. (100\% of $\mathrm{ET}_{0}$ ) gave the highest mean values without significant differences with each of the irrigation treatments 2534 and $1900 \mathrm{~m}^{3} / \mathrm{fed}$ during the first season (80\% of $\mathrm{ET}_{0}$ and $60 \%$ of $\mathrm{ET}_{0}$ ). The result of the second season showed that irrigation treatment with $3167 \mathrm{~m}^{3} / \mathrm{fed}$ significantly gave the highest mean value for No. of seeds/pod trait. Pod length $(\mathrm{cm})$ trait significantly gave the highest mean values with each of the irrigation treatments of 3167 and $2534 \mathrm{~m}^{3} / \mathrm{fed}$ during the first season $\left(100 \%\right.$ of $\mathrm{ET}_{0}$ and $80 \%$ of $\mathrm{ET}_{0}$ ). As for the second season; the obtained data showed that applying $3167 \mathrm{~m}^{3}$ water/fed significantly gave the highest mean value for pod length (cm).

In terms of the tested Faba bean genotypes; regarding pod characteristics, Table (6) showed that each of No. of seeds/plant and pod length $(\mathrm{cm})$ traits are significantly affected $(P \leq=0.05)$ with Faba bean genotypes during the two study seasons of this experiment. In this respect; the pod weight (g) trait did not affect the tested faba bean genotypes. Cleopatra cultivar significantly gave the highest mean values for No. of seeds/pod followed by El-Menia ecotype during the two study seasons. As for the pod length $(\mathrm{cm})$ trait; the data of Table (6) showed that Kafr El-Shikh Faba bean ecotype gave the highest mean values in this regard without significant differences with most of the tested genotypes during the two study seasons.

Regarding the interaction between the two studied independent variables (irrigation water quantities and Faba bean genotypes) on the tested pod characteristics, Table (6) showed that the studied traits significantly affected $(p \leq 0.05)$ with these two independent variables during the two study seasons. Generally, Cleopatra cultivar significantly gave the best results for No. of seeds characteristic with any of the irrigation treatments applied during the two study seasons. As for pod weight $(\mathrm{g})$, the obtained data appeared that irrigation faba bean plants at $100 \%$ of $\mathrm{ET}_{0}$ with most tested Faba bean ecotypes; i.e., Alexandria, El-Behira, Kaf El-Shikh, and El-Menia significantly gave the highest values for pod weight $(\mathrm{g})$ during the two growing seasons. Regarding pod length $(\mathrm{cm})$ characteristics, the data of Table (6) showed that the Irrigation of Faba bean plants at the rate of $3167 \mathrm{~m}^{3} / \mathrm{fed}$. (100\% of $\mathrm{ET}_{0}$ ) significantly gave the best mean values with both Alexandria and El-Behira ecotypes during the two study seasons.

\section{Water requirements}

The crop water requirements as calculated with the Penman-Monteith method (Allen et al., 1998) using the local climatic conditions during the growth stages of Faba been are presented in Table (7). 
Table 6. Mean values of pod characteristics of faba bean genotypes recorded during the seasons of 2017 and 2018.

\begin{tabular}{|c|c|c|c|c|c|c|c|}
\hline \multirow{2}{*}{\multicolumn{2}{|c|}{ Treatments }} & \multicolumn{2}{|c|}{ No. of seeds/pod } & \multicolumn{2}{|c|}{ Pod weight (g) } & \multicolumn{2}{|c|}{ Pod length $(\mathrm{cm})$} \\
\hline & & 2017 & 2018 & 2017 & 2018 & 2017 & 2018 \\
\hline \multicolumn{8}{|c|}{ Irrigation treatment, $\%$ of $\mathrm{ET}_{0}$} \\
\hline \multicolumn{2}{|l|}{100} & $5.27 \mathrm{a}$ & $5.27 \mathrm{a}$ & $21.09 \mathrm{a}$ & $21.28 \mathrm{a}$ & $15.70 \mathrm{a}$ & $14.81 \mathrm{a}$ \\
\hline \multicolumn{2}{|l|}{80} & $5.00 \mathrm{ab}$ & $4.73 \mathrm{~b}$ & $18.07 \mathrm{~b}$ & $17.76 \mathrm{~b}$ & $15.67 \mathrm{a}$ & $14.17 \mathrm{~b}$ \\
\hline \multicolumn{2}{|l|}{60} & $5.00 \mathrm{ab}$ & $4.80 \mathrm{~b}$ & $15.62 \mathrm{c}$ & $15.35 \mathrm{c}$ & $13.80 \mathrm{~b}$ & $12.60 \mathrm{c}$ \\
\hline \multicolumn{2}{|l|}{40} & $4.93 \mathrm{~b}$ & $4.80 \mathrm{~b}$ & $12.71 \mathrm{~d}$ & $11.71 \mathrm{~d}$ & $9.60 \mathrm{c}$ & $8.69 \mathrm{~d}$ \\
\hline \multicolumn{8}{|c|}{ Genotypes } \\
\hline \multicolumn{2}{|c|}{ Alexandria } & $4.42 \mathrm{c}$ & $4.33 \mathrm{c}$ & $16.99 \mathrm{a}$ & $16.43 \mathrm{a}$ & $13.54 \mathrm{ab}$ & $12.07 \mathrm{c}$ \\
\hline \multicolumn{2}{|c|}{ El-Behira } & $4.58 \mathrm{c}$ & $4.54 \mathrm{c}$ & $16.69 \mathrm{a}$ & $16.15 \mathrm{a}$ & $14.13 \mathrm{a}$ & $13.03 \mathrm{ab}$ \\
\hline \multicolumn{2}{|c|}{ Kafr El-Shikh } & $4.58 \mathrm{c}$ & $4.50 \mathrm{c}$ & $16.58 \mathrm{a}$ & $16.64 \mathrm{a}$ & $14.29 \mathrm{a}$ & $13.08 \mathrm{a}$ \\
\hline \multicolumn{2}{|c|}{ El-Menia } & $5.25 \mathrm{~b}$ & $5.00 \mathrm{~b}$ & $16.96 \mathrm{a}$ & $16.70 \mathrm{a}$ & $13.54 \mathrm{ab}$ & $12.49 \mathrm{abc}$ \\
\hline \multicolumn{2}{|l|}{ Cleopatra } & $6.42 \mathrm{a}$ & $6.13 \mathrm{a}$ & $17.15 \mathrm{a}$ & $16.70 \mathrm{a}$ & $12.96 \mathrm{~b}$ & $12.18 \mathrm{bc}$ \\
\hline \multicolumn{8}{|c|}{ Irrigation treatment, \% of ET 0 X Genotypes } \\
\hline \multirow{5}{*}{8} & Alexandria & $4.67 \mathrm{bc}$ & 4.67 cdefg & $21.78 \mathrm{a}$ & $21.80 \mathrm{ab}$ & $18.33 \mathrm{a}$ & $16.90 \mathrm{a}$ \\
\hline & El-Behira & $5.00 \mathrm{bc}$ & $5.00 \mathrm{cde}$ & $20.76 \mathrm{abc}$ & $21.27 \mathrm{ab}$ & $17.00 \mathrm{ab}$ & $16.13 \mathrm{ab}$ \\
\hline & Kafr El-Shikh & $5.00 \mathrm{bc}$ & $5.17 \mathrm{bcd}$ & $21.65 \mathrm{ab}$ & $22.17 \mathrm{a}$ & $14.67 \mathrm{def}$ & $14.03 \mathrm{~cd}$ \\
\hline & El-Menia & $5.33 \mathrm{~b}$ & $5.33 \mathrm{bc}$ & $20.87 \mathrm{ab}$ & $20.92 \mathrm{abc}$ & 14.50 ef & $13.43 \mathrm{cde}$ \\
\hline & Cleopatra & $6.33 \mathrm{a}$ & $6.17 \mathrm{a}$ & $20.40 \mathrm{bc}$ & $20.22 b c$ & $14.00 \mathrm{efgh}$ & $13.57 \mathrm{~cd}$ \\
\hline \multirow{5}{*}{$\infty$} & Alexandria & $4.33 \mathrm{c}$ & $4.00 \mathrm{~g}$ & $17.31 \mathrm{ef}$ & $16.72 \mathrm{efgh}$ & $12.50 \mathrm{~h}$ & $12.67 \mathrm{def}$ \\
\hline & El-Behira & $4.67 \mathrm{bc}$ & $4.33 \mathrm{efg}$ & $17.61 \mathrm{ef}$ & $17.40 \mathrm{ef}$ & 14.17 efg & $15.10 \mathrm{bc}$ \\
\hline & Kafr El-Shikh & $4.67 \mathrm{bc}$ & 4.50 defg & 17.45 ef & $16.98 \mathrm{efg}$ & $16.33 \mathrm{bc}$ & $15.03 \mathrm{bc}$ \\
\hline & El-Menia & $5.00 \mathrm{bc}$ & $5.00 \mathrm{cde}$ & $18.44 \mathrm{de}$ & $18.35 \mathrm{de}$ & $13.33 \mathrm{fgh}$ & $14.07 \mathrm{~cd}$ \\
\hline & Cleopatra & $6.33 \mathrm{a}$ & $5.83 \mathrm{ab}$ & $19.53 \mathrm{~cd}$ & $19.34 \mathrm{~cd}$ & $12.67 \mathrm{gh}$ & $14.00 \mathrm{~cd}$ \\
\hline \multirow{5}{*}{8} & Alexandria & $4.33 \mathrm{c}$ & $4.33 \mathrm{ef}$ & $16.77 \mathrm{fg}$ & $16.25 \mathrm{fghi}$ & $15.33 \mathrm{cde}$ & $11.53 \mathrm{fg}$ \\
\hline & El-Behira & $4.33 \mathrm{c}$ & $4.17 \mathrm{fg}$ & $16.02 \mathrm{gh}$ & $14.91 \mathrm{i}$ & $16.33 \mathrm{bc}$ & $12.83 \mathrm{def}$ \\
\hline & Kafr El-Shikh & $4.33 \mathrm{c}$ & 4.33 efg & $14.41 \mathrm{ij}$ & 15.65 ghi & $16.17 \mathrm{bcd}$ & $14.17 \mathrm{~cd}$ \\
\hline & El-Menia & $5.33 \mathrm{~b}$ & 4.83 cdef & 15.60 ghi & $15.05 \mathrm{hi}$ & 15.50 bcde & $12.63 \mathrm{def}$ \\
\hline & Cleopatra & $6.67 \mathrm{a}$ & $6.33 \mathrm{a}$ & $15.31 \mathrm{hi}$ & $14.89 \mathrm{i}$ & $15.00 \mathrm{cde}$ & $11.83 \mathrm{ef}$ \\
\hline \multirow{5}{*}{ q } & Alexandria & $4.33 \mathrm{c}$ & 4.33 efg & 12.101 & $10.95 \mathrm{j}$ & $8.00 \mathrm{k}$ & $7.17 \mathrm{j}$ \\
\hline & El-Behira & $4.33 \mathrm{c}$ & 4.67 cdefg & $12.38 \mathrm{kl}$ & $11.01 \mathrm{j}$ & $9.00 \mathrm{jk}$ & $8.07 \mathrm{ij}$ \\
\hline & Kafr El-Shikh & $4.33 \mathrm{c}$ & $4.00 \mathrm{~g}$ & $12.80 \mathrm{kl}$ & $11.77 \mathrm{j}$ & $10.00 \mathrm{ij}$ & $9.07 \mathrm{hi}$ \\
\hline & El-Menia & $5.33 \mathrm{~b}$ & $4.83 \mathrm{cdef}$ & $12.92 \mathrm{kl}$ & $12.47 \mathrm{j}$ & $10.83 \mathrm{i}$ & $9.83 \mathrm{gh}$ \\
\hline & Cleopatra & $6.33 \mathrm{a}$ & $6.17 \mathrm{a}$ & $13.35 \mathrm{jk}$ & $12.33 \mathrm{j}$ & $10.17 \mathrm{ij}$ & $9.30 \mathrm{hi}$ \\
\hline
\end{tabular}

Means followed by a similar letter within a column for each parameter are not significantly different at the 0.05 level of probability by L.S.D. test procedure. 
Table 7. Crop water requirements during growth stages of Faba bean

\begin{tabular}{|c|c|c|c|c|}
\hline \multicolumn{5}{|c|}{2017 growing season } \\
\hline & \multicolumn{4}{|c|}{ Irrigation $\left(\%\right.$ of $\left.\mathrm{ET}_{0}\right)$} \\
\hline Growth Stages & $100 \%$ & $80 \%$ & $60 \%$ & $40 \%$ \\
\hline Germination & 185 & 148 & 111 & 74 \\
\hline Vegetative & 521 & 417 & 313 & 209 \\
\hline Reproductive & 640 & 512 & 384 & 256 \\
\hline Pod senescence & 495 & 396 & 297 & 198 \\
\hline Stem senescence & 1325 & 1060 & 795 & 530 \\
\hline Total & 3167 & 2534 & 1900 & 1267 \\
\hline \multicolumn{5}{|c|}{2018 growing season } \\
\hline & \multicolumn{4}{|c|}{ Irrigation $\left(\%\right.$ of $\left.\mathbf{E T}_{0}\right)$} \\
\hline Growth Stages & $100 \%$ & $80 \%$ & $60 \%$ & $40 \%$ \\
\hline Germination & 215 & 172 & 129 & 86 \\
\hline Vegetative & 592 & 474 & 355 & 237 \\
\hline Reproductive & 633 & 507 & 380 & 253 \\
\hline Pod senescence & 514 & 411 & 308 & 206 \\
\hline Stem senescence & 1145 & 916 & 687 & 458 \\
\hline Total & 3100 & 2480 & 1860 & 1240 \\
\hline
\end{tabular}

The water requirements of Faba bean were calculated as $3167,2534,1900$, and $1267 \mathrm{~m}^{3} / \mathrm{fed}$ in the first season and 3100, 2480, 1860, and $1240 \mathrm{~m}^{3} / \mathrm{fed}$ corresponding to $100,80,60$, and $40 \%$ of $\mathrm{ET}_{0}$, respectively.

\section{Irrigation water-use efficiency (IWUE)}

When water is the determining factor of crop production, deficit irrigation can improve WUE, so that available water is better allocated. Irrigation water use efficiency (IWUE) is calculated as the harvested yield $(\mathrm{kg})$ per amount of irrigation water $\left(\mathrm{m}^{3}\right)$ according to the recommendations of the Food and Agriculture Organization (Doorenbos and Kassam, 1979). Among the many biotic and abiotic factors, one of the most important factors affecting productivity as well as the quality of production is the responsible and optimal management of water (Bhriguvanshi et al., 2012).

Table (8) indicated that IWUE significantly was affected by irrigation levels, in which the recoded values decreased with increasing the irrigation levels. The irrigation level of 3167 and $3100 \mathrm{~m}^{3} / \mathrm{fed}$ in the two seasons possessed the lowest values of IWUE. As seen from Table (8), the IWUE ranged between 3.158 and $4.401 \mathrm{~kg} / \mathrm{m}^{3}$ in the first season and between 2.949 and $3.763 \mathrm{~kg} / \mathrm{m}^{3}$ in the second season. Decreasing the irrigation water level resulted in a significant effect on IWUE in which increasing IWUE due to less applied water and more yield.
Also, IWUE significantly affected by Faba bean genotypes (Table, 8). The IWUE ranged between 3.433 and $3.898 \mathrm{~kg} / \mathrm{m}^{3}$ in the first season and between 3.073 and $3.519 \mathrm{~kg} / \mathrm{m}^{3}$ in the second season. The highest values attained for Cleopatra cultivar and the lowest cultivar was Alexandria in the two seasons.

As for the interaction between irrigation water treatments and Faba bean genotypes, the obtained data of Table (8) showed that IWUE significantly affected these two independent variables during the two study seasons. El-Menia cultivar under more stress conditions (1267 and $1240 \mathrm{~m}^{3} / \mathrm{fed}$ in the two seasons, respectively) significantly gave the highest IWUE during the two study seasons $\left(4.758\right.$ and $\left.4.199 \mathrm{~kg} / \mathrm{m}^{3}\right)$. This result could be attributed to the effect of the genotypic characteristic of this cultivar. Thus, the main concern of deficit irrigation is that it maximizes water productivity, although some reduction in yields is observed. In regions where water is the limiting factor for crop production, maximizing water productivity by deficit irrigation is often more economically profitable for a farmer than maximizing yield.

Results of IWUE are presented in (Table, 8), indicated the importance of water deficit to achieve good yields and better usage of water, and this can be mainly attributed to adequate and homogeneous moisture distribution in the root zone in improving crop resistance to water stress (Abdelhamid et al., 2013 and Rahimizadeh et al., 2007). 
Table 8. Irrigation water-use efficiency (IWUE) of Faba bean as affected by irrigation deficit, genotypes, and their interactions.

\begin{tabular}{|c|c|c|c|}
\hline \multirow{2}{*}{ Treatments } & & \multicolumn{2}{|c|}{ IWUE $\left(\mathbf{k g} / \mathbf{m}^{3}\right)$} \\
\hline & & 2017 & 2018 \\
\hline \multicolumn{4}{|c|}{ Irrigation treatment $\left(\%\right.$ of $\left.\mathbf{E T}_{0}\right)$} \\
\hline 100 & & $3.158 \mathrm{~d}$ & $2.949 \mathrm{~d}$ \\
\hline 80 & & $3.408 \mathrm{c}$ & $3.125 \mathrm{c}$ \\
\hline 60 & & $3.719 \mathrm{~b}$ & $3.319 \mathrm{~b}$ \\
\hline 40 & & $4.401 \mathrm{a}$ & $3.763 \mathrm{a}$ \\
\hline \multicolumn{4}{|c|}{ Genotypes } \\
\hline Alexandria & & $3.433 \mathrm{~d}$ & $3.073 \mathrm{c}$ \\
\hline El-Behira & & $3.548 \mathrm{c}$ & $3.147 \mathrm{c}$ \\
\hline Kafr El-Shikh & & $3.712 \mathrm{~b}$ & $3.314 \mathrm{~b}$ \\
\hline El-Menia & & $3.768 \mathrm{~b}$ & $3.394 \mathrm{~b}$ \\
\hline Cleopatra & & $3.898 \mathrm{a}$ & $3.519 \mathrm{a}$ \\
\hline \multicolumn{4}{|c|}{ Irrigation treatment (\% of ET 0$)$ X Genotypes } \\
\hline \multirow{5}{*}{100} & Alexandria & $3.076 \mathrm{kl}$ & $2.942 \mathrm{fgh}$ \\
\hline & El-Behira & $3.126 \mathrm{jkl}$ & $2.894 \mathrm{gh}$ \\
\hline & Kafr El-Shikh & $3.201 \mathrm{ijkl}$ & $2.957 \mathrm{fg}$ \\
\hline & El-Menia & $3.080 \mathrm{kl}$ & $2.902 \mathrm{gh}$ \\
\hline & Cleopatra & 3.307 hij & $3.052 \mathrm{fg}$ \\
\hline \multirow{5}{*}{80.} & Alexandria & 3.0581 & $2.751 \mathrm{~h}$ \\
\hline & El-Behira & $3.268 \mathrm{ijk}$ & $2.985 \mathrm{fg}$ \\
\hline & Kafr El-Shikh & 3.402 ghi & $3.119 \mathrm{def}$ \\
\hline & El-Menia & $3.433 \mathrm{gh}$ & $3.092 \mathrm{efg}$ \\
\hline & Cleopatra & 3.880 cde & $3.677 \mathrm{~b}$ \\
\hline \multirow{5}{*}{60} & Alexandria & $3.606 \mathrm{fg}$ & $3.277 \mathrm{cde}$ \\
\hline & El-Behira & 3.728 ef & $3.302 \mathrm{~cd}$ \\
\hline & Kafr El-Shikh & 3.733 ef & $3.344 \mathrm{c}$ \\
\hline & El-Menia & $3.799 \mathrm{def}$ & $3.383 \mathrm{c}$ \\
\hline & Cleopatra & $3.734 \mathrm{ef}$ & $3.293 \mathrm{cde}$ \\
\hline \multirow{5}{*}{40} & Alexandria & $3.991 \mathrm{~cd}$ & $3.322 \mathrm{~cd}$ \\
\hline & El-Behira & $4.069 \mathrm{c}$ & $3.407 \mathrm{c}$ \\
\hline & Kafr El-Shikh & $4.514 \mathrm{~b}$ & $3.835 \mathrm{~b}$ \\
\hline & El-Menia & $4.758 \mathrm{a}$ & $4.199 \mathrm{a}$ \\
\hline & Cleopatra & $4.671 \mathrm{ab}$ & $4.054 \mathrm{a}$ \\
\hline
\end{tabular}

Means followed by a similar letter within a column for each parameter are not significantly different at the 0.05 level of probability by L.S.D. test procedure. 


\section{CONCLUSION}

It is clear from the results obtained in this research, that different quantities of irrigated water differently affected the growth, productivity, and pod characteristics of Faba bean genotypes, which indicated that the Faba bean genotypes differed in their ability to tolerate differed rates of water shortage. This would help to discover more growth and physiological parameters that might be related to water deficit sensitivity. In semi-arid areas as in Egypt, the use of modern irrigation methods such as the drip irrigation system is necessary due to the limited irrigation water in those areas. Also, calculating the irrigation water use efficiency (IWUE) is very important, so that the maximum water usage under the conditions of water shortage can be maximized even if yield decreased occurred. Cleopatra cultivar, based on the results of this experiment, might be preferred for cultivation compared to the tested Faba bean ecotypes under water deficit conditions.

\section{REFERENCES}

Abdelhamid, M., Ebtisam, I. Eldardiry and M. Abd ElHady.2013. Ameliorate salinity effect through sulphur application and its effect on some soil and plant characters under different water quantities. Agric. Sci., 4 (1): 39-47.

Abdul Muktadir, M.d., K. N. Adhikari, A. Merchant, K. Y. Belachew ,A. Vandenberg, F. L. Stoddard and H. Khazaei.2020. Physiological and Biochemical Basis of Faba Bean Breeding for Drought Adaptation-A Review. Agronomy 10: 1345. doi:10.3390/agronomy10091345.

Abid, G. , R. Ouertani, S. Jebara, H. Boubakri, Y. Muhovski, E. Ghouili, S. Abdelkarim, O. Chaieb, Y. Hidri, S. Kadri, M. El Ayed, S. Elkahoui, F. Barhoumi and M. Jebara.2020. Alleviation of drought stress in faba bean (Vicia fabaL.) by exogenous application of b-aminobutyric acid (BABA). Physiol. Mol. Biol. Plants, 26: 1173-1186.

Adisarwanto, T. and R. Knight.1997. Effect of sowing date and plant density on yield and yield components in the faba bean. Aust. J. Agric. Res., 48: 1161-1168.

Ahmed, A. A. G. 1987. Evaluation of surge irrigation for different field crops. Ph.D. Thesis, Fac. of Agric. Alex. Univ.

Ali, H.M., M.H. Siddiqui, M.H. Al-Whaibi, M.O. Basalah, A.M. Sakran and M. El-Zaidy.2013. Effect of proline and abscisic acid on the growth and physiological performance of faba bean under water stress. Pak. J. Bot., 45: 933-940.

Alghamdi, S.S., A.M. Al-Shameri, H.M. Migdadi, M.H. Ammar, E.H. El-Harty, M.A. Khan and M. Farooq.2015. Physiological and molecular characterization of faba bean (Vicia faba L.) genotypes for adaptation to drought stress. J. Agron. Crop Sci., 201: 401-409.
Allen, R.G., L.S. Pereira, D. Raes and M. Smith.1998. Crop evapotranspiration: Guidelines for computing crop water requirements. FAO Irrigation and Drainage. Paper No. 56. FAO Food and Agriculture Organization of the United Nations, Rome, Italy, p. 300.

Alvino, A., G. Zerbi, L. Frusciante and L.M. Monti.1982. Evaluation of field bean lines grown with a shallow water table maintained at different levels. Field Crop Res., 6: 179-188.

Anjum, S.A., X. Xie, L. Wang, M.F. Saleem, C. Man and W. Lei.2011. Review: Morphological, physiological and biochemical responses of plants to drought stress. Afri. J. Agric. Res., 6(9): 2026-2032.

Asrar, A.W.A. and K.M. Elhindi.2011. Alleviation of drought stress of marigold (Tagetes. erecta) plants by using arbuscular mycorrhizal fungi. Saudi J. Biol. Sci., 18: 9398.

Bennett, J. 2003. Opportunities for increasing water productivity of CGIAR crops through plant breeding and molecular biology. In: J. W. Kijne, R. Barker and D. Molden, editors, Water productivity in Agriculture: limits and opportunities for improvement. CAB International. $p$. 103-127.

Bhriguvanshi, S. R., T. Adak, K. Kumar, V.K. Singh and A. Singh.2012. Impact of fertigation regimes on yield and water use efficiency of mango (Mangifera indica L.) under subtropical conditions. Ind. J. Soil Cons., 40(3): 252-256.

Bota, J., H. Medrano and J. Flexas.2004. Is photosynthesis limited by decreased Rubisco activity and RuBP content under progressive water stress?. New Phytol., 162: 671681.

Cornic, G. 2000. Drought stress inhibits photosynthesis by decreasing stomatal aperture: Not by affecting ATP synthesis. Trend Plant Sci., 5: 187-188.

De Carvalho, M.H.C. 2008. Drought stress and reactive oxygen species: Production, scavenging, and signaling. Pl. Signal. Behav., 3: 156-165.

Dennet, M.D., J.F. Elston, and J.R. Milford.1979. The effect of temperature on the growth of individual leaves of Vicia faba L. in the field. Ann. Bot., 43: 197-208.

Doorenbos, J. and A. H. Kassem.1979. Yield Response to Water. FAO paper 33, 193 p.

El-Nadi, A.H. 1969. Water relations of beans I. Effects of water stress on growth and flowering. Exp. Agric., 5: 195207.

El-Nadi, A.H. 1970.Water relations of beans. II. Effects of differential irrigation on yield and seed size of broad beans. Exp. Agric., 6: 107-111.

Elston, J.F., A.J. Karamanos, A.H. Kassam, and R.M. Wadsworth.1976.The water relations of the field bean crop. Philosophical Transactions of the Royal Society of London. Series B, Biological Sci., 273(927): 581-591. 
FAOSTAT, Food and Agriculture Organization.2018. Available online: http://www.fao.org/faostat/en/\#data/QC.

FAOSTAT, Food and Agriculture Organization.2018. Available online:http://www.fao.org/faostat/en/\#data/QC/ visualize.

Farooq, M., M. Hussain, A. Wahid and K.H.M. Siddique.2012. Drought stress in plants: An overview. In Plant Responses to Drought Stress from Morphological to Molecular Features; Aroca, R., Ed.; Springer-Verlag: Berlin, Germany, pp. 1-36.

Farooq, M., S.M.A. Basra, A. Wahid, Z.A. Cheema, M.A. Cheema and A. Khaliq.2008. The physiological role of exogenously applied glycinebetaine in improving drought tolerance of fine grain aromatic rice (Oryza. sativa L.). J. Agron. Crop Sci., 194: 325-333.

Fereres, E. and M. A. Soriano.2007.Deficit irrigation for reducing agricultural water use. Special issue on "Integrated approaches to sustain and improve plant production under drought stress". J. Exp. Bot., 58:147159.

Finch-Savage, W.E. and J.F. Elston.1982. The effect of temperature and water stress on the timing of leaf death in Vicia faba L. Ann. Appl. Biol., 100: 567-579.

Flexas, J., J. Bota, F. Loreto, G. Coranic and T.D. Shakey.2004.Diffusive and metabolic limitation to photosynthesis under drought and salinity in $\mathrm{C}_{3}$ plants. $\mathrm{J}$. Pl. Biol., 6: 269-279.

Geerts, S., D. Raes, M. Garcia, O. Condori, J. Mamani, R. Miranda, J. Cusicanqui, C. Taboada and J. Vacher.2008. Could deficit irrigation be a sustainable practice for quinoa (Chenopodium quinoa Willd.) in the Southern Bolivian Altiplano? Agric. Water Manage., 95: 909-917.

Ghassen, A., K. Hessini, M. Aouida, I. Aroua, J.P. Baudoin, Y. Muhovski, G. Mergeai, K. Sassi, M. Machraoui, F. Souissi and M. Jebara.2017. Agro-physiological and biochemical responses of faba bean (Vicia faba L. var. 'minor') genotypes to water deficit stress. Biotechnol. Agron. Soc. Environ., 21(2): 146-159.

Ghosh, S.G., K. Asanuma, A. Kusutani and M. Toyota.2000. Effect of moisture stress at different growth stages on the amount of total nonstructural carbohydrate, nitrate reductase activity, and yield of potato. Japanese J. Trop. Agric., 44(3): 158-166.

Hawtin, G.C. and P.D. Hebblethwaite.1983. Background and history of faba bean production. In: P.D. Hebblethwaite (Ed.), The Faba Bean (Vicia faba L.), pp. 3-22. Butterworths, London, England.

Karam, F., N. Amacha, S. Fahed, T. El Asmar and A. Domínguez.2014.Response of potato to full and deficit irrigation under semiarid climate: agronomic and economic implications. Agric. Water Manag., 142:144151.

Karamanos, A.J. 1978.Water stress and leaf growth of field beans (Vicia faba L.) in the field: leaf number and total leaf area. Ann. Bot., 42: 1393-1402.
Khan, H.R.; W. Link, T.J. Hocking and F.L. Stoddard.2007. Evaluation of physiological traits for improving drought tolerance in faba bean (Vicia faba L.). Plant Soil, 292: 205-217.

Kumar, R., S. S. Solankey and M. Singh.2012. Breeding for drought tolerance in vegetables. Vegetable Sci., 39 (1): 115.

Loss, S.P. and K.H.M. Siddique.1997.Adaptation of faba bean (Vicia faba L.) to dryland Mediterranean-type environments I. Seed yield and yield components. Field Crop. Res., 53: 17-28.

Mohan, C. S., A. D. Sarena, T. Richard and R. A. Steward. 1982. Faba bean in Nile valley. Report on the first phase of the ICARDA/ IFAD Nile valley project (1979- 1982).

Moran, R. 1982. Formulae for determination of chlorophyllous pigments extracted with $\mathrm{N}, \mathrm{N}$-dimethyl formamide. Plant Physiol., 69: 1376-1381.

Mwanamwenge, J.; S.P. Loss, K.H.M. Siddique and P.S. Cocks.1999. Effect of water stress during floral initiation, flowering, and podding on the growth and yield of faba bean (Vicia faba L.). Eur. J. Agron., 11: 1-11.

Nanda, H.C., M. Yasin, C.B. Singh and S.K. Rao.1988. Effect of water stress on dry matter production, harvest index, seed yield, and its components in faba bean (Vicia faba L.). FABIS Newsletter, 21: 26-30.

NASA.2020. NASA Prediction of Worldwide Energy Resources. The POWER Project. https://power.larc.nasa.gov/\#page-top

Nautiyal, P., V. Ravindra, P. Zala and Y. Joshi.1999. Enhancement of yield in groundnut following the imposition of transient soil - moisture stress during the vegetative phase. Exp. Agric. 35: 371-385.

Ouzounidou, G., I.F. Ilias, A. Giannakoula and I. Theocharidou.2014.Effect of water stress and $\mathrm{NaCl}$ triggered changes on yield, physiology, biochemistry of broad bean (Vicia faba L.) plants and on quality of harvested pods. Biologia, 69: 1010-1017.

Parry, M.A.J., P.J. Androlojc, S. Khan, P.J. Lea and A.J. Keys. 2002.Rubisco activity: Effects of drought stress. Ann. Bot., 89: 833-839.

Paryy, M.A.J., P.J. Madgwick, J.F.C. Carvalho and P.J. Andralogic. 2007. Prospects for increasing photosynthesis by overcoming the limitations of Rubisco. J. Agric. Sci., 45: 31-43.

Pereira, L. S., T. Oweis and A. Zairi. 2002. Irrigation management under water scarcity. Agric. Water Manag., 57: 175-206.

Plies-Balzer, E., T. Kong, S. Schubert and K. Mengel.1995. Effect of water stress on plant growth, nitrogenase activity, and nitrogen economy of four different cultivars of Vicia faba L. Euro. J. Agro., (4) 2: 167-173.

Radwan, F. I. and Wafaa, H. Mohamed.2005. Influence of planting density, biofertilizers inoculation, and superphosphate application to soil on growth and yield component of faba bean plants. J. Adv. Agric. Res. (Fac. Agric. Saba Bash) 10 (1): 145-162. 
Rahimizadeh, M., D. Habibi, H. Madani, G.N. Mohammadi, Mehraban and A. Sabet. 2007.The effect of micronutrients on antioxidant enzymes metabolism in sunflower (Helianthus annuus L.) under drought stress. HELIA, 30(47):288-294.

Reynolds, M. and R. Tuberosa. 2008. Translational research impacting on crop productivity in drought-prone environments. Curr.Opin. Plant Biol., 11: 171-179.

Ricciardi, L., G.P. Polignano and C. De Giovanni.2001. Genotypic response of faba bean to water stress. Euphytica 118: 39-46.

Ricciardi, L. and P. Steduto.1988. Plant breeding for resistance to drought. III. Leaf water potential and stomatal resistance variations in Vicia faba L. FABIS Newsletter, 20: 21-24.

Shao, H., S. Jiang, F.Li, L. Chu, C. Zhao, M. Shao and X. Zhao.2007. Some advances in plant stress physiology and their implications in the system biology era. Biointerafaces, 54: 33-36.

Sharma, B.R., D. Molden and S. Cook.2015. Water use efficiency in agriculture: measurement, current situation and trends. In. Drechsel, P, Heffer, P., Magan, H., Mikkelsen, R., Wichlens, D. (Eds.) Managing Water and Fertiliser for Sustainable Intensification. Paris, France: Int. Fertilizer Association. pp. 39-64.

Siddiqui, M.H., M.Y. Al-khaishany, M.A. Al-Qutami, M.H. Al-Whaibi, A. Grover, H.M. Ali, Mona, S. Al-Wahibi and Najat, A. Bukhari. 2015. Response of different genotypes of faba bean plant to drought stress. Int. J. Mol. Sci., 16: 10214-10227.

Snedecor, G. H. and W. C. Cochran.1980. Statistical Methods. $7^{\text {th }}$ ed. Iowa State University Press, Ames., Iowa, U.S.A.
Sorrells, M.E., A. Diab and M. Nachit. 2000. Comparative genetics of drought tolerance.In : Royo C. (ed.), Nachit M. (ed.), Di Fonzo N. (ed.), Araus J.L. (ed.). Durum wheat improvement in the Mediterranean region: New Challenges, Zaragoza (Spain): CIHEAM, 2000. p. 191201.

Sprent, J.I. 1972. The effects of water stress on nitrogen-fixing root nodules. IV. Effects on whole plants of Vicia faba and Glicine max. New Phytol., 71: 603-611.

Sprent, J.I. 1976. Water deficits and nitrogen-fixing roots nodules. In: T.T. Kozlowski (Ed.), Water Deficits and Plant Growth, Vol. IV: Soil Water Measurements, Plant Responses, and Breeding for Drought Resistance, pp. 103152. Academic Press, New York.

Sprent, J.I., A.M. Bradford and C. Norton.1977. Seasonal growth patterns in field beans (Vicia faba) as affected by population density, shading, and their relationship with soil moisture. J. Agric. Sci. Camb., 88: 293-301.

Steduto, P. and R. Albrizio.2005.Resource use-efficiency of field-grown sunflower, sorghum, wheat, and chickpea. II. Water use efficiency and comparison with radiation use efficiency. Agric. For. Meteorol., 130: 269-281.

Steduto, P., T. C. Hsiao and E. Fereres.2007.On the conservative behavior of biomass water productivity. Irrig. Sci., 25: 189-207.

Stoddard, F.L. 1986. Effects of drought on autofertility in faba beans. FABIS Newsletter, 15: 22-26.

Tamaki, K. and J. Naka .1971.Physiological studies of the growing process of broad bean plants. III. Effects of soil moisture on the growth and the variations of chemical components on the various organs. Tech. Bull. Fac. Agric., Kagawa University, 22: 73-82.

Xia, M.Z. 1994.Effects of soil drought during the generative development phase of faba bean (Vicia faba) on photosynthetic characters and biomass production. J. Agric. Sci., 122: 67-72.

Yordanov, I., V. Velikova and T. Tsonev.2003. Plant responses to drought and stress tolerance. Bulg. J. Plant Physiol., Special Issue, 187-206. 


\section{الملخص العربي}

\section{إستجابة بعض التراكيب الوراثية للقول لظروف نقص مياه الري المنزرع فى الأراضى الرملية}

منى محمد يسرى جابر ، سامح عبد المنعم محمد موسى، جمال عبد الناصر خليل

ومحتوى الأوراق من الكلوروفيل والمحصول الطازج من القرون/ فدان معنويا بمعدلات الري. أظهرت النتائج المتحصل عليها وجود انخفاض معنوي في قيم معظم هذه

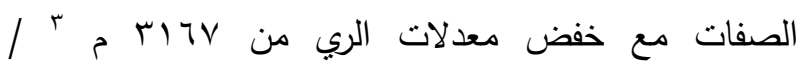

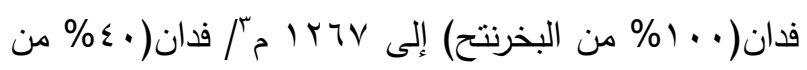

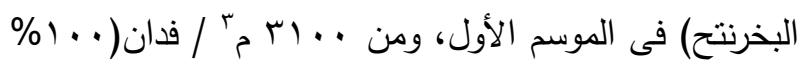

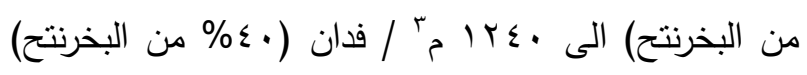

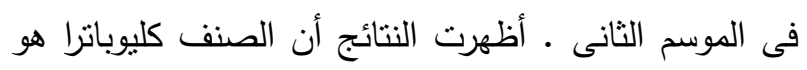
أفضل التراكيب الوراثية المختبرة من حيث كفاءة إستخدام مياه

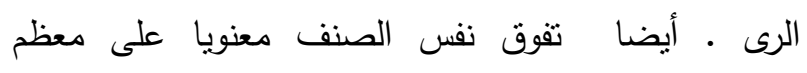
السلالات المحلية من الفول من حيث قوة النمو والانتاجية

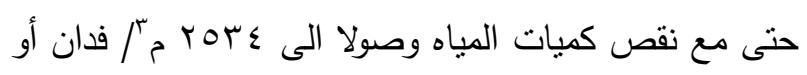

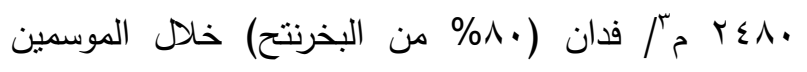
الأول والثانى على التوالى. أظهرت نتائج الدراسة أنه تحت ظروف هذه التجربة، فإنه يمكن ترشيد استخدام مياه الرى الرى

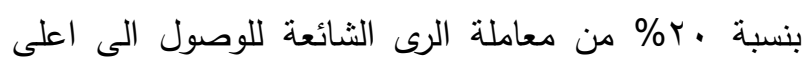

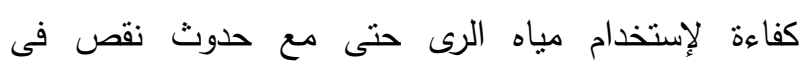
المحصول خاصة فى المناطق شبه الجافة محدودة المياه.
الفول هو المحصول البقولي رقم واحد مصر من حيث المساحة المزروعة واجمالي الإنتاج والاستهلاك والاعتم ولماد عليه بشكل كبير كمصدر رخيص للبرونين. الإنتاج المحلي من زراعته يغطي فقط اء٪ من حجم الاستهلاك والباقي

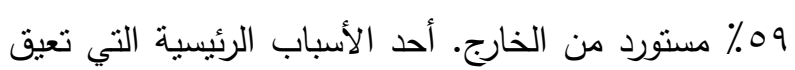
التوسع الأفقي لزراعة المحاصيل في مصر هو نقص مياه الري. لذلك أجريت هذه الدراسة تحت نظام الري بالتتقيط لتقنين إستخدام مياه الري وزيادة كفاءة استخدامها، ومن ثم زيادة إنتاجية الفول في ظل ظروف عجز المياه. تمت

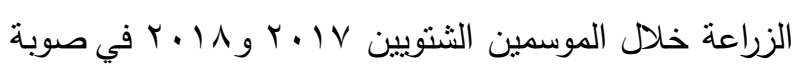
كلية الزراعة ساباباشا محافظة الإسكندرية، مصر • زرعت أربعة سلالات محلية من الفول وصنف تجاري (كليوبانرا) تحت نظام الري بالتتقيط لتقييمهم في ظل ظروف نقص

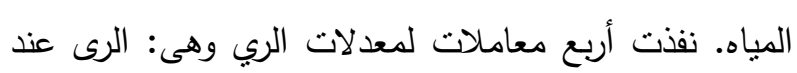

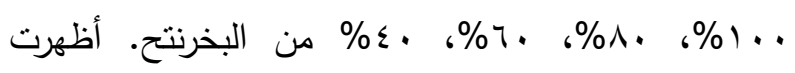
النتائج المكتسبة أن التراكيب الوراثية للفول المختبرة اختلفت فيما بينها في معظم الصفات المدروسة سواء الصفات الخضرية والمحصول ومكوناته وخصائص القرون. تأثرت معظم الصفات المدروسة وخاصة الصفات الخضرية 